\title{
REMOTE SENSING FOR URBAN TREE CANOPY CHANGE DETECTION WITH LANDSAT SATELLITE DATA IN NNAMDI AZIKIWE UNIVERSITY AWKA - NIGERIA
}

\author{
John A. Ogbodo ${ }^{* 1,3}$, Loretta M. Obimdike ${ }^{2}$ and Yason Benison ${ }^{3}$ \\ ${ }^{1}$ Department of Forestry and Wildlife, Nnamdi Azikiwe University Awka, Anambra State, Nigeria \\ ${ }^{2}$ NYSC, State Department of Forestry, Ministry of Agriculture and Natural Resources, \\ No.1, Garden Avenue, Enugu, Enugu State, Nigeria \\ ${ }^{3}$ Sustainable TransEnvironment International Foundation, STEi Foundation: \\ www.steifoundation.org, Gombe, Gombe State, Nigeria
}

Received: 26 April 2020, Revised: 19 October 2020, Accepted: 21 October 2020

\begin{abstract}
REMOTE SENSING FOR URBAN TREE CANOPY CHANGE DETECTION WITH LANDSAT SATELLITE DATA IN NNAMDI AZIKIWE UNIVERSITY, AWKA - NIGERIA. Urban tree canopy within a university boundary is a measure of the university's tree cover as a percentage of its total land area. The overall objective of the present study is to conduct a spatio-temporal change analysis of urban tree canopy in Nnamdi Azikiwe University Awka-Nigeria. Landsat data of years 1991, 2001, 2011 and 2019 were analysed using Maximum Likelihood Classifier and Confusion Matrix Spatial Analyst in ArcGIS 10.7.1 software. In terms of tree cover loss, there is a steady rate of decrease from -31.59 ha between 1991 and 2001; $-82.32 \mathrm{ha}(2001 / 2011)$ and $-64.53 \mathrm{ha}(2011 / 2019)$. Whereas, at an initial land area of 9.40 ha in 1991, physical infrastructural development is progressively increased with 16.92 ha between 1991 and 2001; 43.79 ha 2001/2011 and 12.37 ha between 2011 and 2019. The dominant drivers of tree cover change in the study area related to the expansion of physical infrastructures and sprawling agriculture as a result of encroachers into the study area. In conclusion, tropical forests within university campuses face many threats, such as those posed by unregulated physical infrastructural development and a lack of investment and management of forest relics. As a recommendation, Nigerian universities should invest and conserve their existing forested landscapes towards promoting land resources in line with Sustainable Development Goals number 15 (SDG-15) strategies.
\end{abstract}

Keywords: Change Detection, Kappa coefficient, Landsat Remote Sensing, Nnamdi Azikiwe University Awka, Tree Canopy, Urban sprawl

PENGINDERAAN JAUH UNTUK MENDETEKSI PERUBAHAN KANOPI POHON KAWASAN PERKOTAAN MENGGUNAKAN DATA SATELIT LANDSAT DI NNAMDI AZIKIWE UNIVERSITY AWKA-NIGERIA. Kanopi pohon di kawasan perkotaan seperti kanopi pohon diperbatasan wilayah suatu universitas merupakan ukuran tutupan pohon wilayah universitas sebagai suatu persentase dari total luas lahan. Penelitian ini menganalisis perubahan spatio-temporal dari kanopi pohon perkotaan di wilayah Nnamdi Azikiwe University Awka-Nigeria. Data Landsat tabun 1991, 2001, 2011, dan 2019 dianalisis menggunakan Maximum Likelibood Classifier dan Confusion Matrix Spatial Analyst pada perangkat lunak. ArcGIS 10.7.1. Dalam bal penurunan tutupan pohon, hasilmya menunjukkean penurunan yang stabil dari -31,59 ha antara tabun 1991 dan 2001; -82,32 ha (2001/2011) dan -64,53 ba (2011/2019). Pada tahun 1991, luasan awal seluas 9,4 ha pada tabun 1991, pembangunan infrastruktur fisik semakin meningkat seluas 16,92 ba antara tabun 1991 dan 2001; 43,79 ba 2001/2011 dan 12,37 ha antara tabun 2011 dan 2019. Pendorong utama perubahan tutupan pohon di wilayah studi terkait dengan perluasan infrastruktur fisik dan perladangan berpindah dari penduduk desa yang bertetangga, melakukan perambahan ke wilayah yang dianalisis. Dari penelitian dapat disimpulkan bahwa butan tropis di kawasan kampus termasuk. yang menghadapi banyak ancaman, seperti yang ditimbulkan oleh pembangunan infrastruktur fisik yang tidak diatur dan kurangnya investasi dan pengelolaan peninggalan butan. Untuk itu, disarankan agar universitas-universitas di Nigeria berinvestasi dan melestarikan lanskap butan yang ada untuk mempromosikan pengelolaan sumber daya lahan, mengikuti pencapaian strategi tujuan pembangunan berkelanjutan nomor 15 (SDG-15).

Kata kunci: Deteksi perubahan, koefisien Kappa, penginderaan jauh Landsat, Nnamdi Azikiwe University Awka, kanopi pohon, perluasan kota

\footnotetext{
*Corresponding author: ja.ogbodo@unizik.edu.ng and steifoundation@yahoo.com
} 


\section{INTRODUCTION}

The growing human populations require sustainable space and natural resources management. Natural resources management (NRM) is the sustainable use of resources that come from nature (i.e. forest, agriculture, land, water and air) towards optimising their economic, social and cultural values for both present and future generations. Thus, the principle of NRM further conforms to the concept of sustainable development which requires that policies are executed towards achieving economically viable, socially acceptable and ecologically sound natural resources management.

Specifically, the Sustainable Development Goals (SDGs) number 15, (on landcover/ land-use change and terrestrial biodiversity conservation), is pivotal for natural resources management actions taken at both corporate and public spheres of the human society (World Bank, 2009). For instance, the increasing demands for natural resources by humans are primarily supplied in un-sustainable manners, especially in developing countries. As such, a myriad of social, economic and environmental consequences arising from competing claims for natural resources exploration, usage and consumption (World Bank, 2009). For example, the effects of natural events combined with the ever-increasing human requirements for economic activities and urban sprawl, are putting high demands on environmental resources. According to Livesley, Escobedo and Morgenroth (2016), tropical forest availability has significantly dwindled through urban sprawling.

Any university campus could be an urban prototype, because, of the degree of urban indices that are operational within its boundary. FAO - Food and Agriculture Organization of the United Nations (2012) and Zubair (2006) both assert that urban sprawl is a crucial driver of tropical deforestation in the world. According to Ogbodo, Tembe and Peter (2017) expansion of university-based infrastructures is among the competing factors that drive tropical deforestation in the southern part of Nigeria.
This situation creates conflicts that result in unsustainable consumptions of land resources, thereby, placing high pressures, particularly on the availability of tropical forest (World Bank, 2009; Zubair, 2006). Furthermore, tropical deforestation is an issue of major concern that has numerous consequences on thermal comfort (Xiao et al., 2006; Xiaojun, 2011). Severe heat has negative impacts on human well-being and efficiency; especially, as it relates to teaching and learning within a university campus. Naturally, the sunlight that produces heat waves is captured by the forests.

A forest is any land area of more than 0.5 hectares with trees higher than five meters and a canopy cover of more than $10 \%$ (FAO, 2012). Despite that, tropical forests have limited spatial extent; they continue to play critical roles in global exchanges of energy, in biogeochemical cycling (Ogbodo, Oke \& Dagba, 2015). Literature asserts that forests are the largest terrestrial sequester of carbon dioxide $\left(\mathrm{CO}_{2}\right)$ from the atmosphere (Ontl et al., 2020). However, it has become increasingly alarming that impacts of anthropogenic climate change are compromising the supplies of ecosystem services from dwindling forest resources; thus threatening human societies in many sectors coupled with their attendant effects on human survival and well-being. FAO (2012) estimated that around thirteen (13) million hectares per year had been lost to deforestation activities in the Afrotropic ${ }^{1}$ region.

FAO (2012) defined the term deforestation as the conversion of forest cover into the other land use. In other words, it is a process by which forest cover is converted into another land cover type such as bare land, farmland, and building. Thus, forest cover conversion is of great concern to scientists because, among other environmental issues, it often contributes to increased levels of global warming (short term) and climate change (over two and a half decades) (Ogbodo, Wasige, Shuaibu, Dube \& Anarah, 2019; Wimrly and Ohmann, 2004). The environmental issue arises because when forests are cleared or degraded, their stored

$1=$ Tropical area 
carbon is released into the atmosphere as carbon dioxide $\left(\mathrm{CO}_{2}\right)$ (FAO, 2001). In other words, $\mathrm{CO}_{2}$, a greenhouse gas that contributes to global warming, is captured by forest trees.

Forest is, therefore, a type of landcover at any given area. FAO (1997) defined, landcover as (a) vegetation (example: natural or planted vegetation); (b) human-made constructions (such as buildings); and (c) water bodies, rocks, icecaps, bare land and dunes; that are found on the earth surface. Studying land cover change is technically referred to as land cover change detection. According to Kotoky, Dutta \& Borah (2012), a land cover change is identified by observing the state of an Earth's features at different time intervals. Usually, there are five causes of land cover change (Lambin \& Geist, 2006): (a) ecological and geomorphological processes such as vegetation succession and soil erosion; (b) human-induced alterations of vegetation cover and landscapes such as deforestation and forest degradation; (c) long-term natural changes in climatic conditions; (d) inter-annual climate variability; lastly (e) greenhouse effects resulting from human-induced activities. Signs of land cover change can be observed physically, with Earth Observation (EO) technology (Sonti, 2015).

Earth Observation (EO) technology such as satellite remote sensors, in conjunction with ground-based data, are capable of observing, monitoring, measuring and modelling various components of natural ecosystems. For instance, remote sensing methods are widely used to acquire data about the earth surface from a distance either from a satellite or airborne platform (Ogbodo et al., 2019). According to Lillesand, Kiefer, and Chipman (2008), several remotely sensed data used for mapping and spatial analysis are collected as reflected electromagnetic radiation. They are afterwards, processed into a digital image that can be overlaid with other spatial data. To assess and monitor human-induced land cover changes, one must in effect separate the signal of inter-annual land cover change from the regular seasonal changes that one would expect to observe in the tropical forest (Sonti, 2015).
Change detection methods with remote sensing are basically grouped into visual analysis and classification approaches, among a few others (Lambin \& Geist, 2006).

The effects of natural events combined with the ever-increasing human requirements for economic activities and urban sprawl are putting high demands on tropical forests. This situation creates conflicts that result in over-depletion of forest resources. The impacts of anthropogenic climate change are compromising with the supplies of ecosystem services from dwindling natural resources; thus threatening human societies in many developing countries coupled with their attendant effects on human survival and well-being.

Nevertheless, there is an absence of requisite information on forest cover change rates for Nigerian universities. Scarce state-of-the-art information on forest cover dynamics in any Nigerian university system can limit effective monitoring of their forest resource; investment opportunities for contemporary forestry research and conservation; and forestry policymarking to support the Reducing Emissions from Deforestation and forest Degradation (REDD+) global climate change framework.

The overall objective of this study is to assess the Spatio-temporal change analysis of urban tree canopy in Nnamdi Azikiwe University Awka-Nigeria with Landsat satellite remote sensing data, 1991-2019. The outcomes of this study could be useful for the promotion of climate-smart campuses as a panacea for a university-based strategy for achieving sustainable climate change mitigation and adaptation in Nigeria.

\section{MATERIAL AND METHOD}

\section{A. Study Area}

\section{Description of the Study Area}

Nnamdi Azikiwe University Awka (NAU) (Figure 1) is a Federal University established in 1991 and located in the south-eastern part of Nigeria, precisely, within a suburban environment in the Anambra State's Capital City of Awka. The spatial size of the NAU 


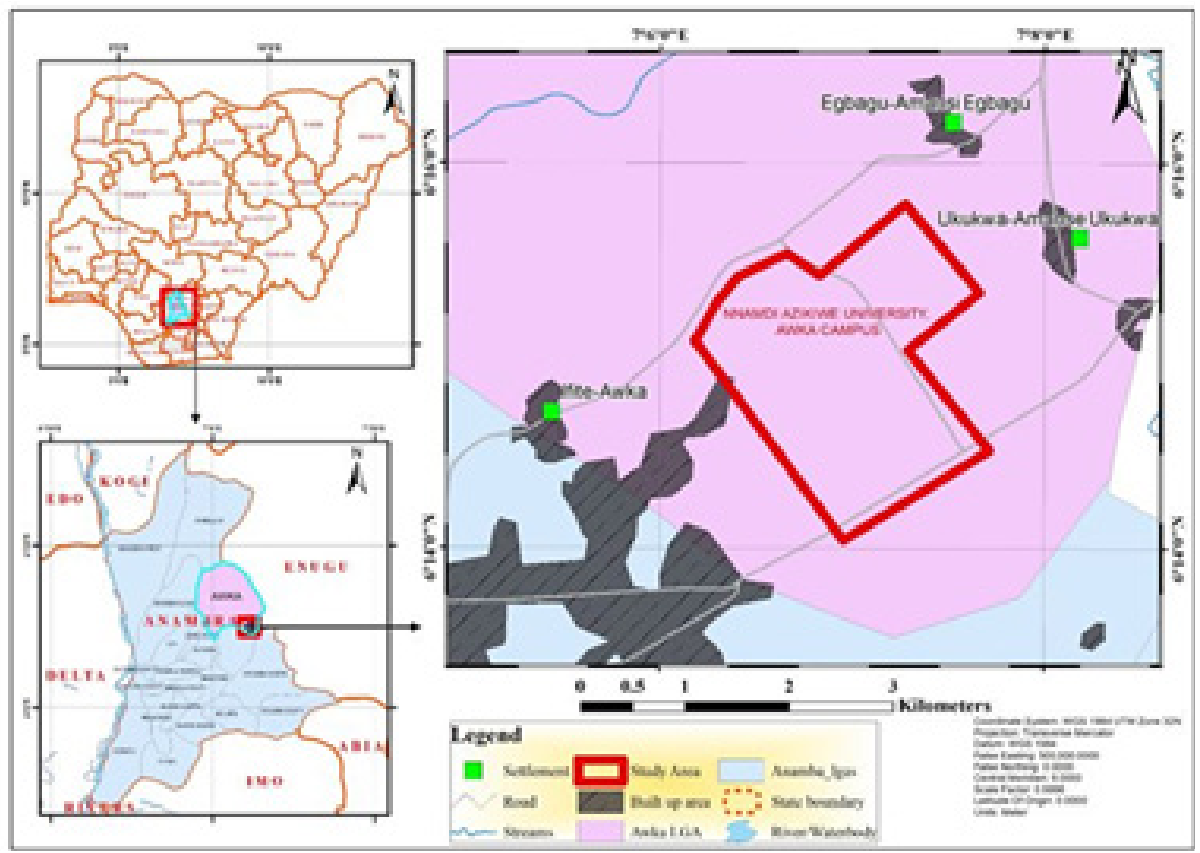

Figure 1. Map of study area showing Nnamdi Azikiwe University Awka-Nigeria

Awka campus is approximately $4.99 \mathrm{~km}^{2}$ (an equivalent of 499 Hectares) ${ }^{2}$. The study area is situated on the geographic coordinates of $6^{\circ} 14^{\prime} 38.4^{\prime \prime} \mathrm{N}$ and $7^{\circ} 07^{\prime} 18.7^{\prime \prime} \mathrm{E}$.

\section{Vegetation of Awka}

Awka, the seat of NAU, is in the tropical rainforest zone of Nigeria. Awka is situated on a fertile tropical valley. The original rainforest cover has been lost due to expansion of farming systems and human settlements. Thus, derived savannah grassland currently dominates the original primary tropical rainforest estates.

\section{Climate of Awka}

The study area experiences two distinct climatic seasons brought about by the two predominant winds that rule Awka, namely: the south-western monsoon winds from the Atlantic Ocean and the north-eastern dry winds from across the Sahara desert. The monsoon

\footnotetext{
${ }^{2}$ It is worth-mentioning that, at the time of writing this paper, there is no previous literature on the internet which has provided an actual size of the study area. Thus, we computed the size of the study area (in Sq.km and hectares) using the Geographical Information System (GIS) Shapefile (i.e. the red polygon in Figure 1). The above referenced shapefile was obtained from the NAU's Department of Geoinformatics and Surveying.
}

winds from the Atlantic create six months of heavy tropical rains, which occur between April and July, followed by a short dry period in August lasting one to two weeks (nowadays) with the rains resuming in September and ceasing in October. The wet (rainy) season is followed by five months of the dry period from November to March marked by the Harmattan wind. Harmattan is a dry, and dusty wind and a grey haze characterise it. The haze usually limits visibility and blocking the sun's rays. Generally, the intensity of Harmattan in the study area increases from the beginning of every November until January.

\section{Temperature}

Extreme dry heat period occurs around February and March. The temperature in Awka is generally $27-30^{\circ} \mathrm{C}$ between May and January but rises to $32-34^{\circ} \mathrm{C}$ between February and April, with the last few months of the dry season marked by intense heat.

\section{B. Remote Sensing Data}

Four Landsat imagery, namely: Landsat 4 Thematic Mapper (TM), dated January 7, 1991; Landsat 7 Enhanced Thematic Mapper (ETM+) of February 19, 2001; ETM+ 
(dated, January 30, 2011) and Landsat 8 Operational Land Imagery (OLI) of January 12, 2019; were acquired from the United States Geological Survey (USGS) Archive which is accessible at http://earthexplorer.usgs. gov. The selected image dates were based on image-data availability over the study area and low percentage-cloudiness on the images. The afore-listed satellite images were analysed for forest cover change phenomenon (Akbari \& Mamanpoush, 2006; Yuan, Sawaya, Loeffelholz \& Bauer, 2005). The spatial resolution of one pixel of the images used is $30 \mathrm{~m}$.

\section{Geometric Correction}

The provider already did the geometric correction for the Landsat images before their acquisition for this present study. The used remotely sensed data were geometrically corrected to the World Geodetic System 1984 (i.e. WGS-84) datum. In the present study, satellite images were re-projected to WGS84UTM Zone32N to ensure accurate metric measurements of the landcover classes in the study area.

\section{Collection of Ground-Truthing Data for Validation}

To validate the classified maps, ground truth (reference) data together with their Global Positioning System (GPS) coordinates were obtained from Google Earth (Tilahun \& Teferie, 2015). Google Earth was used to ascertain how many ground truth pixels are correctly classified. Ground truthing was done in comparison with the visual analysis of the Landsat imagery used and based on the authors' prior knowledge of the area. Therefore, fifty (50) regions of interest (AOI) were purposefully sampled per land cover class in the study area (Lillesand et al., 2008).

\section{E. Remote Sensing for Forest Cover Classification and Change Detection}

\section{Satellite Image Classification}

The unsupervised classification was first performed on the images. The core objective of unsupervised image classification is to automatically categorise all pixels in an image into land cover classes. In the present study, the Landsat classification legend comprises of five land cover classes, namely built-up area, forest land, agricultural land, bare land and grassland in the study area. The aforementioned landcover classes were made based on spectral characteristics of the Landsat image analysis (Akbari \& Mamanpoush, 2006). Next, supervised classification was done by following three stages that included training data sets, classification and output. Training samples were taken for each land cover type that was identified on the supervised classification output. The classification was done by using maximum likelihood classifier (Torahi, 2013; Congalton, Oderwald, \& Mead, 1983).

\section{Change Detection Analysis:}

In order to detect, assess, and map the forest cover change in the study area, from the period from 1991 (year of Nnamdi Azikiwe University establishment) to 2019 (current year of this research), various datasets from Landsat sensors of TM, ETM, and OLI were used. Change detection is the process of identifying differences in the state of an object or phenomena by observing it at different times (Yuan et al., 2005; Singh, 1989). From visual and digital interpretations of the satellite images, different land cover categories were distinguished in the study area, and emphasis was mainly given to green and infrastructure classes. Hence, forest areas and urban sprawl indices such as buildings and roads were detected and analysed from the imagery, based on Lung and Schaab (2010) land cover classification techniques. The percentage landc over change (trend) was computed with Equation 1 (Zubair, 2006):

$$
\% \text { Landcover }=\frac{\text { Observed landcover } \text { change }}{\text { Sum of landcover change }} \times 100
$$

\section{F. Computation of Accuracy Assessment}

The confusion matrix is usually used as the quantitative method of characterising satellite image classification accuracy (Adam, Elhag \& Salih, 2013). A confusion matrix is a table that shows the correspondence between the 
classification results and the referenced imagedata (Ukrainski, 2016). Diagonal cells of a confusion matrix table contain the number of correctly identified pixels. Therefore, Equation 2 was applied (Ukrainski, 2016) in determining the overall accuracy in the percentage of the land cover classification.

Overall Accuracy $(\%)=\frac{\text { Number of correctly sampled pixels per AOI }}{\text { Total number of sampled pixels of the AOls }} \cdot(2)$

Similarly, user's accuracy and producer's accuracy types, including errors of commission and errors of omission were all calculated in the present study. According to Ukrainski (2016), for any class, errors of commission occur when a classification procedure assigns pixels wrongly to any other land cover class. A number of pixels mistakenly assigned to a class can be found in column cells of the class above and below the main diagonal. Furthermore, for any land cover class, errors of omission occur during class overlapping pixels. From the main diagonal, the omitted pixels is located in the row cells to the left and right of the matrix.

\section{G. Computation of Kappa Coefficient}

Ukrainski (2016) explained the Kappa coefficient (denoted as $\mathrm{K}$ ) as a measure of how the classification results compare to values assigned by chance. $\mathrm{K}$ reflects the difference between the actual agreement and the agreement expected by chance. It can take values from $0-$ 1. If Kappa coefficient equals to 0, there will be no agreement between the classified image and the reference image. Therefore, the higher the Kappa coefficient, the more accurate the classification is. Equation 3 (Lillesand et al., 2008) was used to determine the Kappa statistic for our classification analyses.

Kappa $=\frac{\text { Observed accuracy }- \text { Chance agreement }}{1-\text { Chance agreement }}$

\section{RESULT AND DISCUSSION}

\section{A. Results}

\section{Analysis of Land Cover Trend, from 1991} - 2019, in the Study Area

After classifying the satellite images from four different dates, land cover map for the periods, results of how much areas of land cover types changed in the study area is presented in Table 1. From Table 1, the classification shows the initial land cover types as follows: $56.16 \%$ (forest cover), $26.05 \%$ (grassland), $14.87 \%$ (cropland) $1.88 \%$ (built-up area $=$ physical infrastructure) and $1.03 \%$ (bare land). Figure 2 shows the landcover map for the period under investigation.

\section{Comparing the Forest Cover and Build- up Area Changes in the Study Area}

Spatial pattern in Figure 3 indicates a steady tree cover loss from - 31.59 ha $(1991 / 2001)$ through -82.32 ha $(2001 / 2011)$ to -64.53 ha (2011/2019), and physical infrastructural development (Figure 4) progressively increased with 16.92 ha between 1991 and 2001; 43.79 ha 2001/2011 and 12.37 ha during 2011 - 2019 period.

Table 1: Landcover change detection 1991 to 2019

\begin{tabular}{|c|c|c|c|c|c|c|c|c|c|c|c|}
\hline \multirow{2}{*}{$\begin{array}{l}\text { Landcover } \\
\text { type }\end{array}$} & \multicolumn{2}{|c|}{1991} & \multicolumn{2}{|c|}{2001} & \multicolumn{2}{|c|}{2011} & \multicolumn{2}{|c|}{2019} & \multicolumn{3}{|c|}{$\begin{array}{l}\text { Tree cover Area } \\
\text { Difference }(\mathrm{Ha})\end{array}$} \\
\hline & $\begin{array}{l}{ }^{a} \text { Area } \\
\text { (Ha) }\end{array}$ & $\%$ & $\begin{array}{l}\text { ' Area } \\
(\mathrm{Ha})\end{array}$ & $\%$ & $\begin{array}{l}{ }^{c} \text { Area } \\
(\mathrm{Ha})\end{array}$ & $\%$ & $\begin{array}{l}\text { d Area } \\
(\mathrm{Ha})\end{array}$ & $\%$ & $\mathrm{~b}-\mathrm{a}$ & $c-b$ & $\mathrm{~d}-\mathrm{c}$ \\
\hline Agric. land & 74.19 & 14.87 & 45.36 & 9.11 & 53.19 & 10.66 & 59.00 & 11.82 & -28.83 & 7.83 & 5.81 \\
\hline Bare land & 5.16 & 1.03 & 20.21 & 4.06 & 31.58 & 6.33 & 108.67 & 21.77 & 15.05 & 11.37 & 77.09 \\
\hline Built up & 9.40 & 1.88 & 26.32 & 5.28 & 70.11 & 14.05 & 82.48 & 16.53 & 16.92 & 43.79 & 12.37 \\
\hline Forest & 280.29 & 56.16 & 248.70 & 49.93 & 166.38 & 33.34 & 101.85 & 20.41 & -31.59 & -82.32 & -64.53 \\
\hline Grassland & 130.01 & 26.05 & 157.54 & 31.63 & 177.85 & 35.63 & 147.09 & 29.47 & 27.53 & 20.31 & -30.76 \\
\hline Total & 499.06 & 100.00 & 498.13 & 100.00 & 499.09 & 100.00 & 499.09 & 100.00 & & - & \\
\hline
\end{tabular}




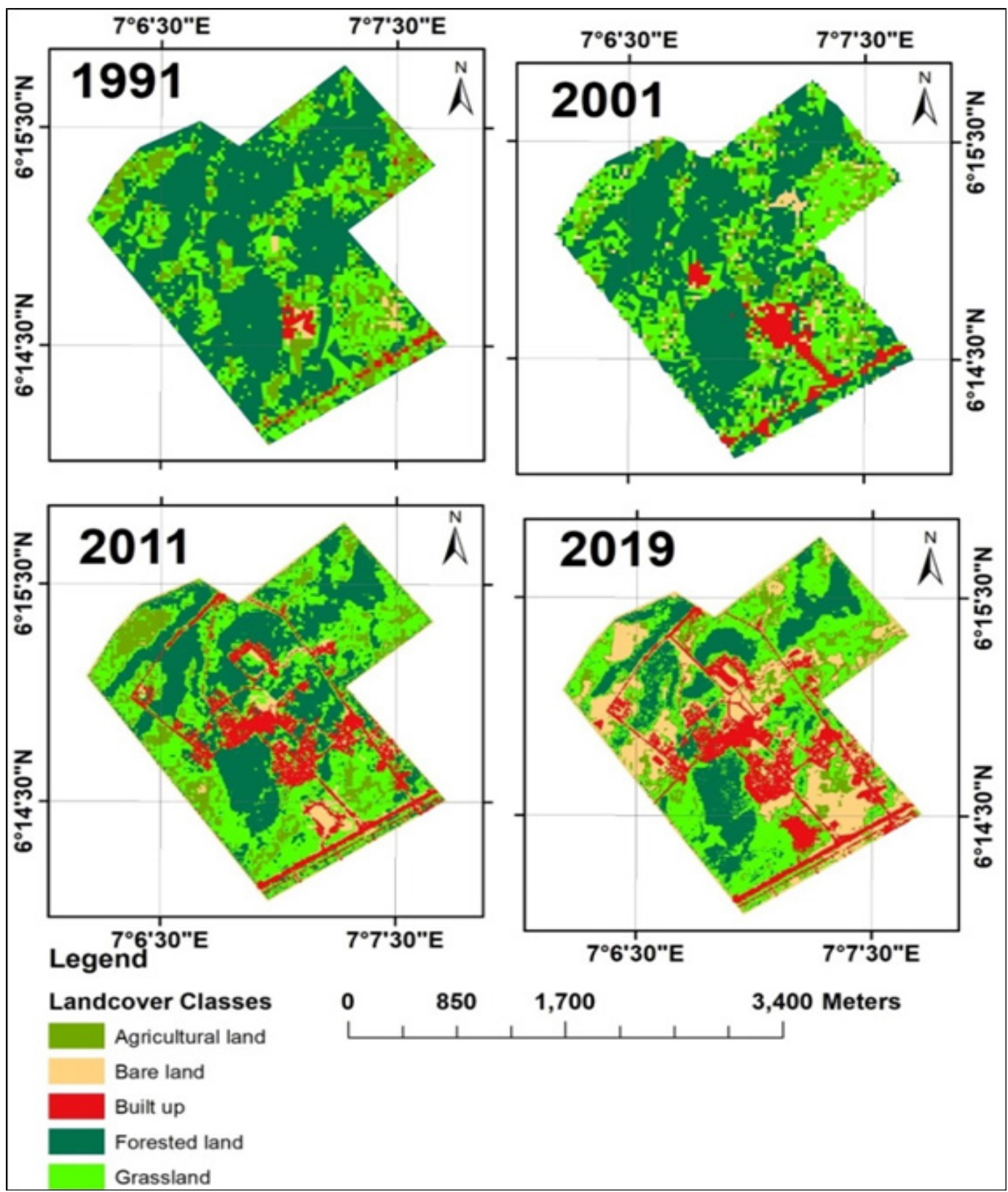

Figure 2. Landcover classification map of the study area

\section{Results of the Computation of Accuracy Assessment}

Figure 5 presents the distribution and the referenced data for 2019 used for validation of the processed remotely sensed data in this present study. Table 2 presents the results of accuracy assessment of the Landsat 8 and the referenced data from Google Earth coupled with visual ground observations in 2019 (i.e. the year of ground-truthing data).

\section{Result of Kappa Coefficient \\ Computation}

Therefore, the Kappa coefficient value means that there is $98 \%$ classification agreement between the classified Landsat 8 imagery and the referenced data for each of the years 1991 and 2019. In summary, the Kappa statistical results for the 1991 and 2019 Change Detection analysis (Figure 6) stands at 0.981 and 0.982, respectively (Table 3 ); meaning that both the 


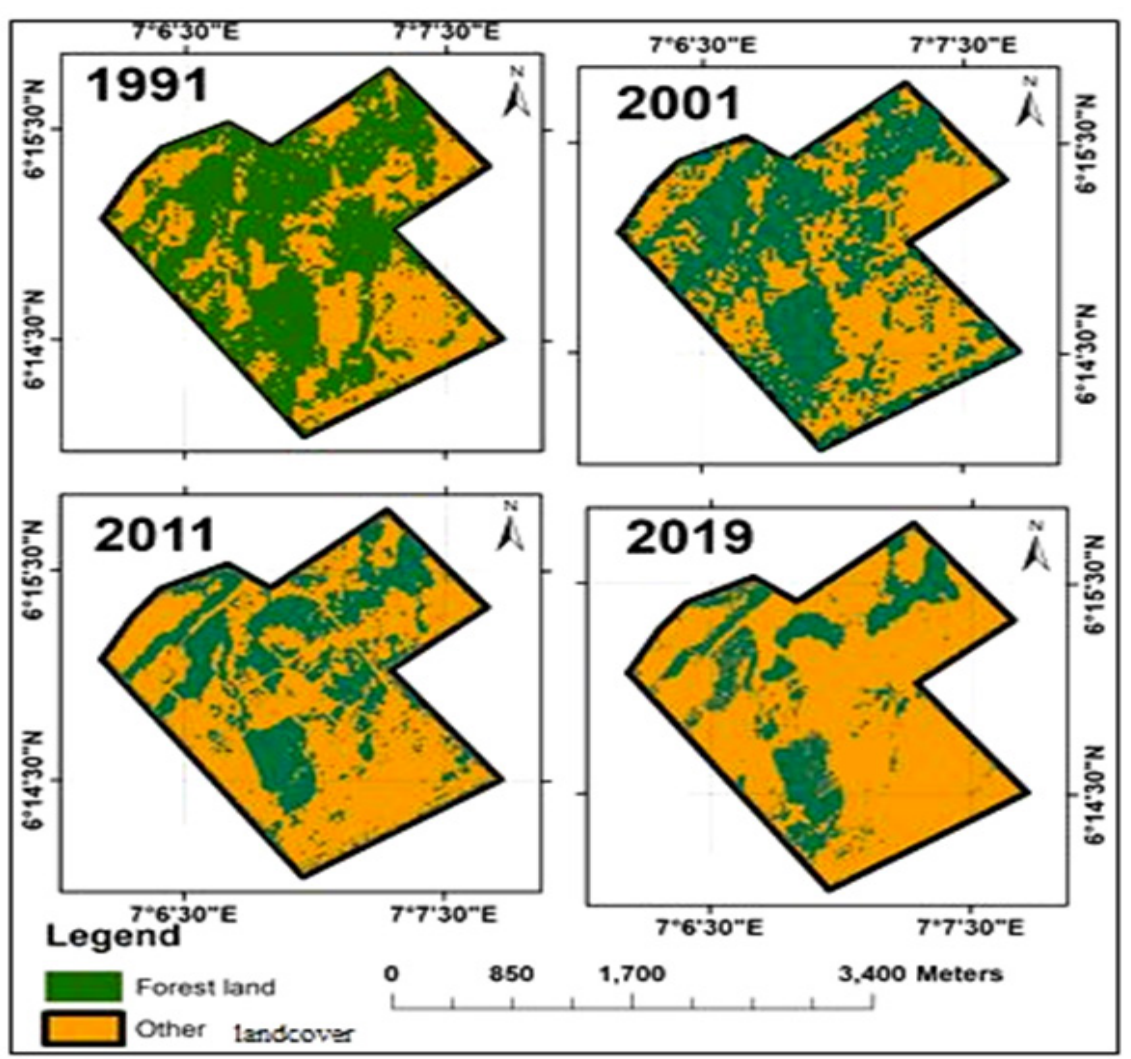

Figure 3. Forest cover map of the study area

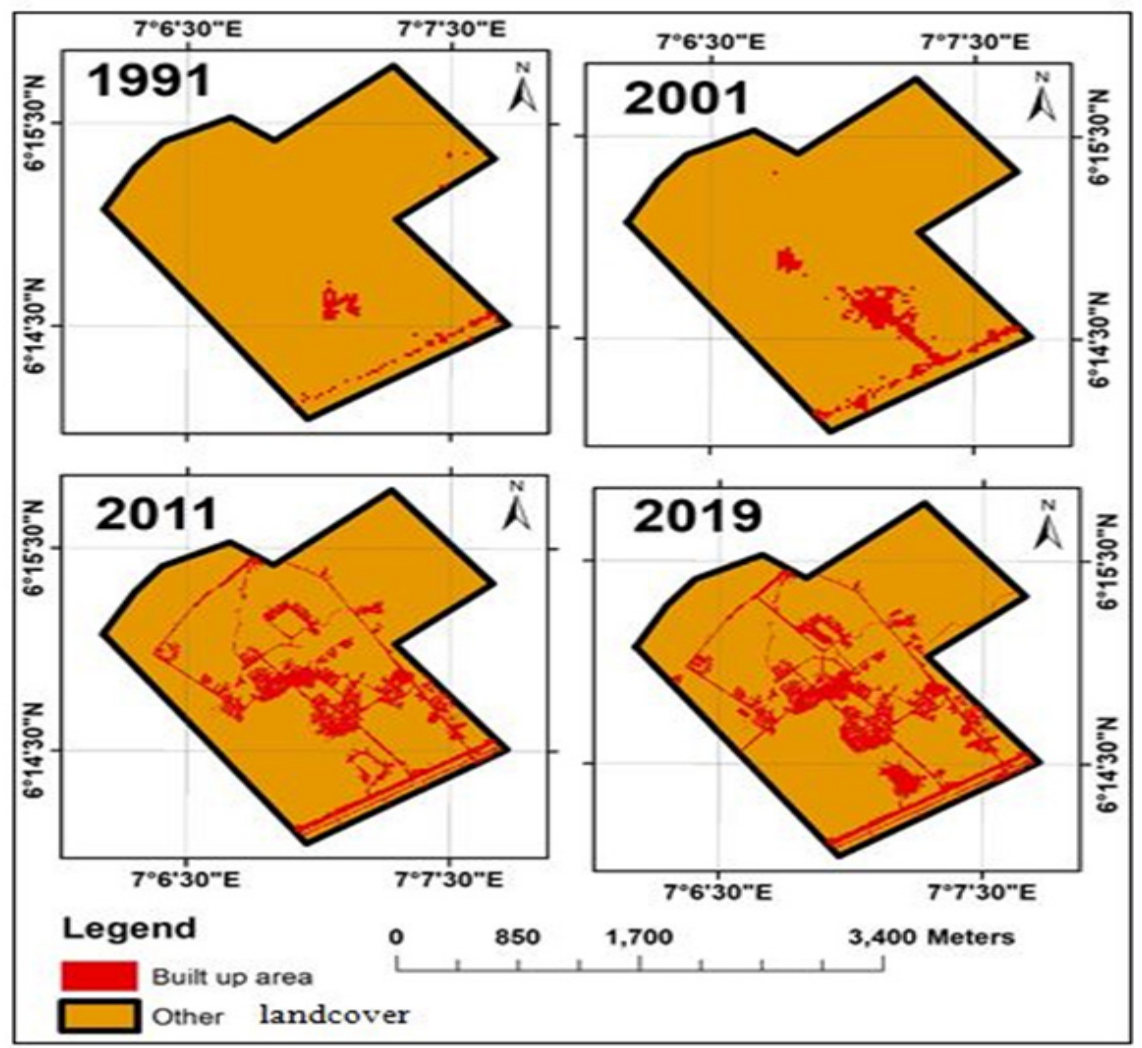

Figure 4. Built-up area change map 


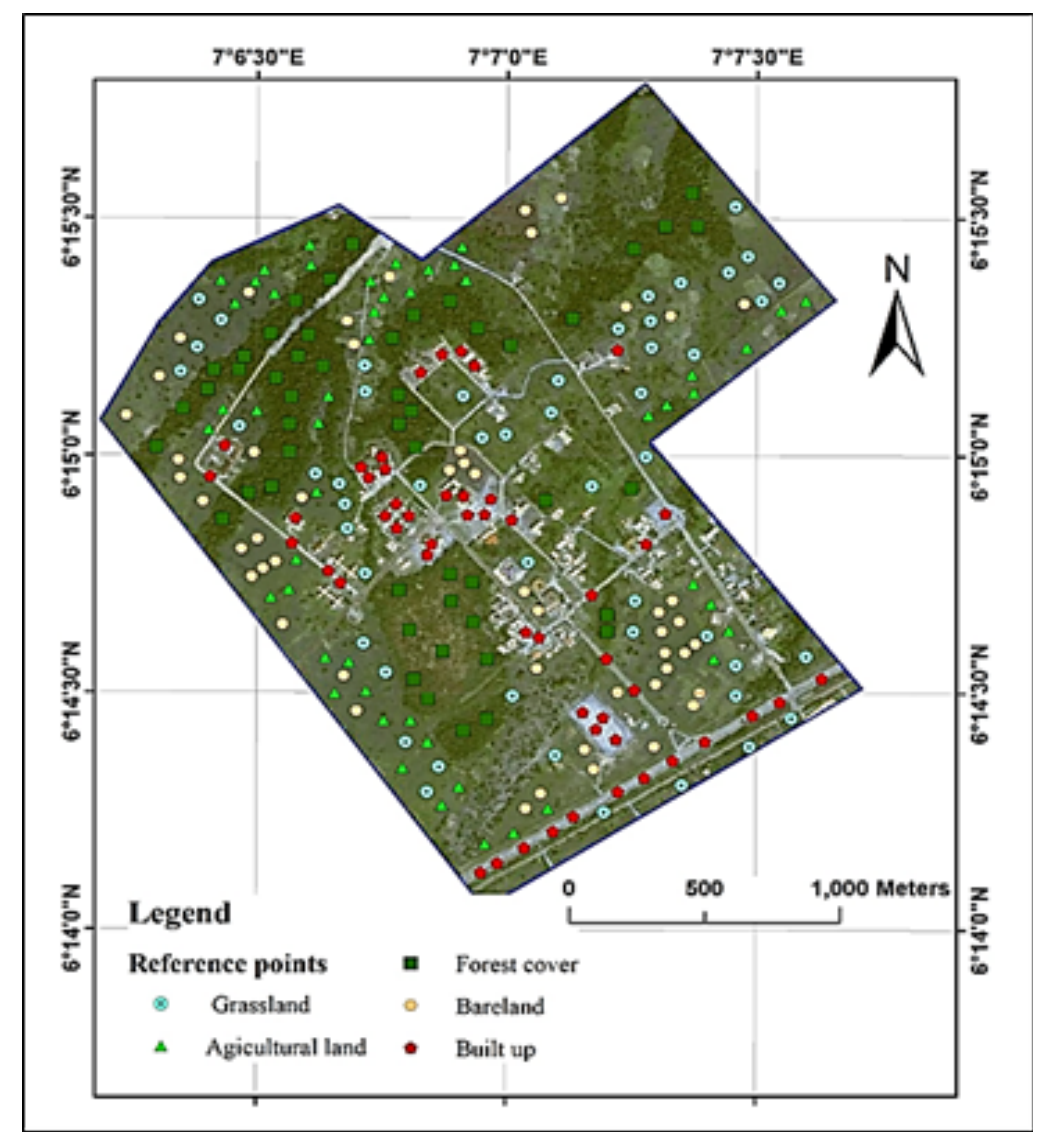

Figure 5. Distribution of ground control points in the study

Table 2: Confusion matrix of classification analysis for the Landsat image 2019

\begin{tabular}{|c|c|c|c|c|c|c|c|c|c|}
\hline \multirow{8}{*}{ 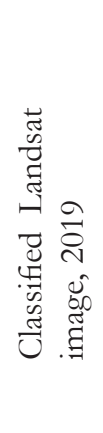 } & \multicolumn{7}{|c|}{ Ground truthing data } & \multirow[b]{2}{*}{$\begin{array}{l}\text { Omission } \\
\text { Error }\end{array}$} & \multirow{2}{*}{$\begin{array}{l}\text { Users } \\
\text { Accuracy } \\
(\%)\end{array}$} \\
\hline & Class & Forest & $\begin{array}{l}\text { Agric. } \\
\text { land }\end{array}$ & Grassland & Built-up & Bare land & Total & & \\
\hline & Forest & 44 & 4 & 2 & 0 & 0 & 50 & 0.120 & 88 \\
\hline & Agric. land & 0 & 38 & 1 & 1 & 0 & 40 & 0.050 & 95 \\
\hline & Grassland & 7 & 13 & 30 & 0 & 0 & 50 & 0.400 & 60 \\
\hline & Built-up & 0 & 1 & 0 & 34 & 9 & 44 & 0.227 & 77 \\
\hline & Bare land & 0 & 2 & 8 & 0 & 29 & 39 & 0.256 & 74 \\
\hline & Total & 51 & 58 & 41 & 35 & 38 & 223 & \multicolumn{2}{|c|}{$\begin{array}{l}\text { Overall Accuracy = } \\
78.50 \%\end{array}$} \\
\hline
\end{tabular}

$$
\begin{gathered}
\begin{array}{c}
\text { Kappa } \\
=\frac{(44+38+30+34+29)-[(51 * 50)+(58 * 40)+(41 * 50)+(35 * 44)+(38 * 39)]}{1-[(51 * 50)+(58 * 40)+(41 * 50)+(35 * 44)+(38 * 39)]} \\
=\frac{(175)-(9942)}{1-(9942)} \\
=\frac{-(9767)}{-(9941)} \\
\because \text { Kappa }=\mathbf{0 . 9 8 2}
\end{array}
\end{gathered}
$$


Table 3: Confusion matrix of classification analysis for the Landsat image 1991

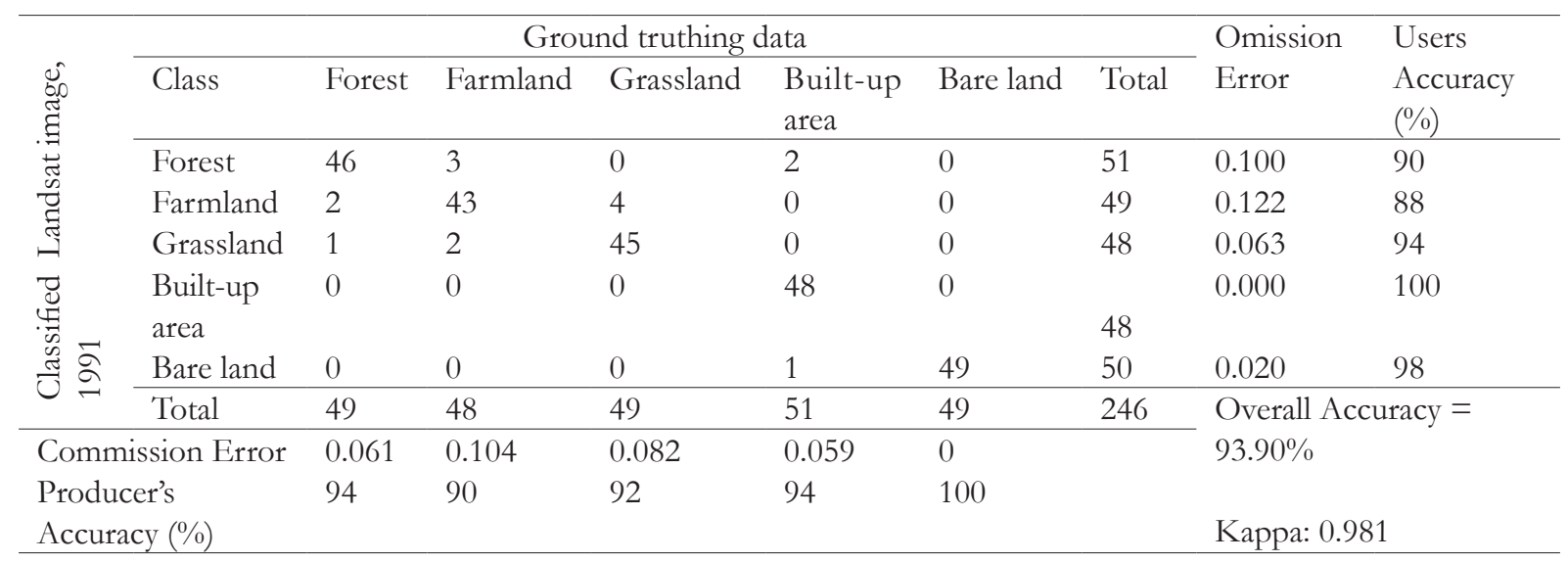

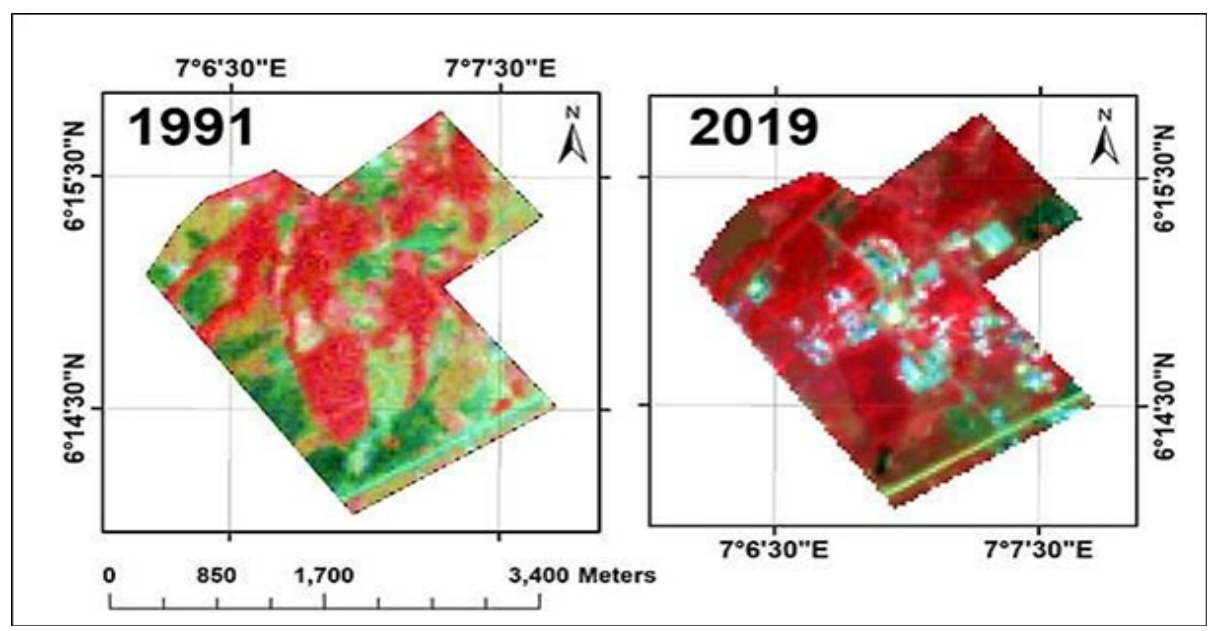

Figure 6. Overview of pronounced buildings in 2019 as against 1991 Landsat image

classified imagery and the reference datasets are very close, expressing high accuracy.

In conclusion, there is a tremendous rise in human-made structures in 2019 as compared to 1991 (Figure 7) in the case study area. The change in the built-up area includes administrative buildings, lecture halls, medical facility, worship buildings, road infrastructure, student hotels, workshops and other buildings such as university auditorium, etc. The university authority carried out the overall landcover change within the period investigated without a corresponding investment rate of reforestation. Thus, tropical forests within the Nigerian university campus face many threats, such as those posed by unregulated physical infrastructural development and a lack of investment and management of forest relics.

\section{B. Discussion}

According to Nigeria's Federal Department of Forestry (2019), Nigeria's forest vegetation declines due to deliberate removal of trees to pave the way for mineral exploitation and sprawling agriculture. Furthermore, Ogbodo et al. (2017) express that expansion of infrastructures is one of the factors that drive deforestation in public universities that are majorly situated within the natural forest part of Southern Nigeria. The finding of this study is in agreement to Ogbodo et al. (2017) which asserts that huge physical development projects 


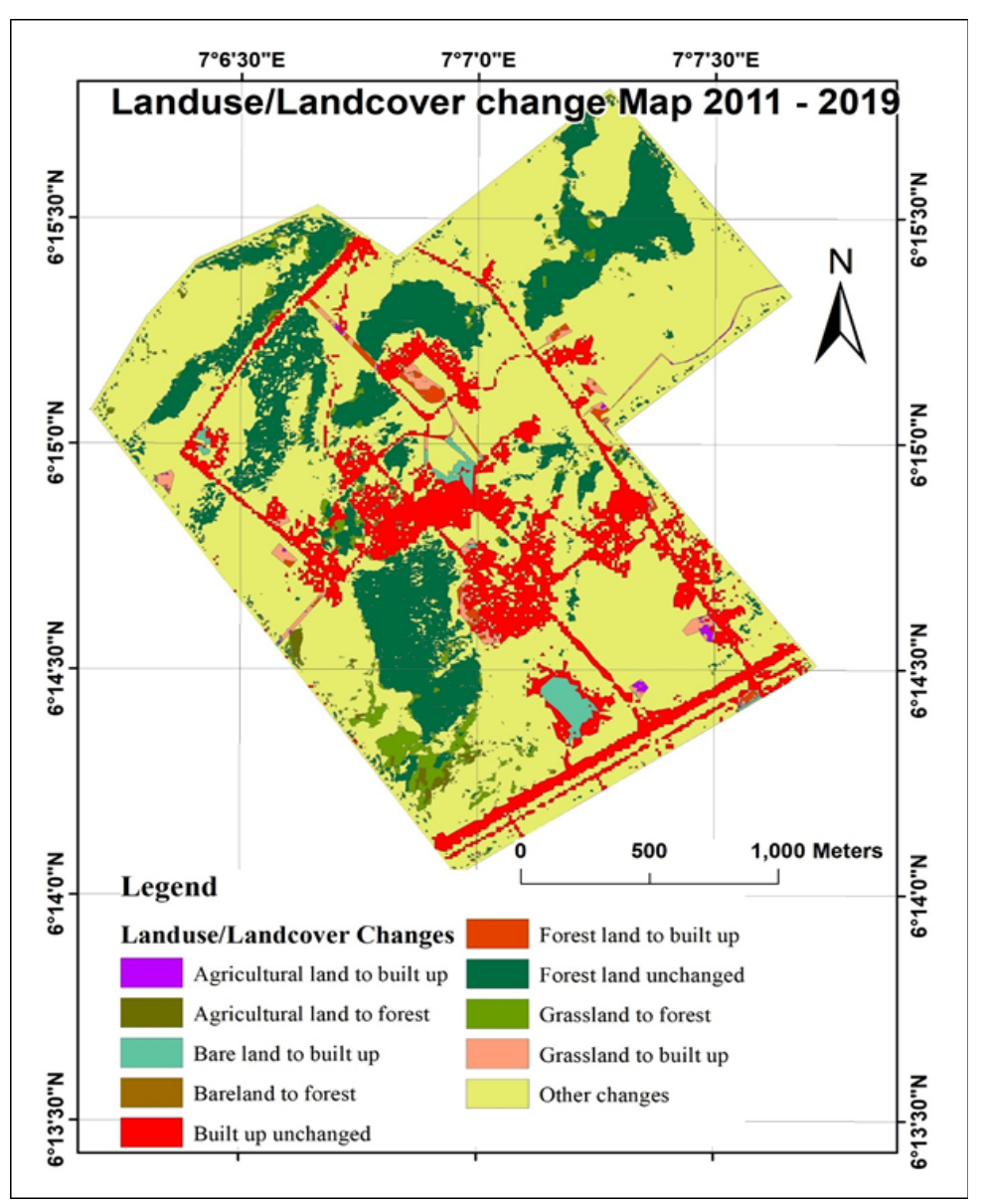

Figure 7. Landcover change map of Nnamdi Azikiwe University Awka Campus

in public universities are primarily financed by Tertiary Education Trust Fund (TETFund) which usually leads to the replacement of forestland with buildings such as lecture theatres, administrative blocks, student hotels, without corresponding TETFund-sponsored reforestation or afforestation in Nigerian universities. Furthermore, Zubair (2006) expressed that, massive deforestation rates are experienced within the Afrotropic region of the world due to human-induced activities from sprawling agriculture and increase in built-up areas. Therefore, sustenance of the foregoing scenario within Nigerian universities campuses will negate the principle of sustainable development.

Brundtland (1987) defined sustainable development as a development that meets the needs of the present human generations without jeopardizing future generations from meeting their own needs of the same environmental resources. Thus, imbibing the tenets of sustainable development can be achieved in Nigeria when university authorities mainstream urban forestry guidelines into their master plans on physical infrastructural developments. According to Sustainable Development Solutions Network (SDSN) - Australia (2017) universities should always commit to ensuring safe and green campuses. To achieve SDG15 in Nigeria, practising of urban tree canopy strategies by university authorities is, therefore, highly imperative. Urban tree canopy is referred to as a measure of a university's tree cover as a percentage of the total land area (Salbitano, Borelli, Conigliaro \& Chen, 2016). Thus, mapping of urban tree canopy can support vital thermal heat comforts within university communities across Nigeria. Thermal comfort on campus cities of universities has become more and more important, especially within the context of global warming and rapid urban 
sprawling (Xiao et al., 2006). Urban thermal comfort would influence human outdoor activities and the utilisation of urban spaces (Xiaojun, 2011). Severe heat has negative impacts on human well-being and efficiency; especially, as it relates to teaching and learning within a university campus.

Therefore, it is essential to infer in the present study that, an increase in forest coverage within any university campus could be one of the most effective ways of lowering heat waves. Evans (2014) expresses that trees serve as a natural air conditioner. This is because; the cooling effect capability of a single tree can be equivalent to the output capacity of ten (10) room-sized air conditioners when operating 20 hours a day.

Based on the foregoing, in adherence to the slogan of the United Nations Sustainable Development Goals (SDGs) of leaving no one/ sector behind, measuring of the ever-changing forest cover pattern within university campuses in tropical regions is imperative for actualising the SDGs, particularly, SDG-11 (sustainable cities/campuses), SDG-13 (combating climate change and its impacts), and SDG-15 (sustainable forest conservation) by 2020 in Nigeria.

\section{CONCLUSION AND \\ RECOMENDATION}

In conclusion, therefore, there is a tremendous rise in human-made structures within the study area without a corresponding investment in reforestation projects. With an initial land area of 9.40 ha in 1991, physical infrastructural development progressively increased with 16.92 ha in the 1991/2001 period; 43.79 ha 2001/2011 and 12.37 ha between 2011 and 2019. The Kappa statistical results for the 1991 and 2019 Change Detection analysis respectively stand at 0.981 and 0.982 ; meaning that, both the classified imagery and the reference datasets are in full agreement with each other. In conclusion, there is a tremendous rise in human-made structures at the study area within the period investigated, without a corresponding investment rate in reforestation. Thus, tropical forests within the Nigerian university campus face many threats, such as those posed by unregulated physical infrastructural development and a lack of investment and management of forest relics.

For this study, three salient recommendations are at this moment proffered as a way forward. Firstly, there is a need to ascertain the availability and distribution of trees-outside-the-forest within the study area before concluding as to the capability of Nnamdi Azikiwe University Awka-Nigeria to achieve SDGs (numbers 13 and 15) by 2030. Secondly, it is imperative that the Nnamdi Azikiwe University's masterplan is updated to meet-up with global best practices on new forest conservation measures. Thirdly, there is a need to scale-up this study to other universities in Nigeria towards obtaining a holistic outcome for sustainable forestry development goals in Nigeria.

In this research, the 'water' feature was not classified as one of the land cover types in the study area because the cloud-free Landsat imagery available for the study area falls within the dry season period. Future research needs to combine radar and Landsat data towards obtaining accurate land cover classes in the wetseason period in the study area.

\section{ACKNOWLEDGEMENT}

We would like to acknowledge the valuable contributions made by the editors and all the reviewers towards improving this article.

\section{REFERENCES}

Adam, A. H. M., Elhag, A. M. H., \& Salih, A. M. (2013). Accuracy assessment of land use and land cover classification (LU/LC) "Case study of Shomadi area Renk County Upper Nile State, South Sudan." International Journal of Scientific and Research Publications, 3(5), 1712-1717.

Brundtland, G. H. (1987). Report of the world commission on environment and development: Our common future. Retrieved from https://sustainabledevelopment. 
un.org/content/documents/5987ourcommon-future.pdf on 1 January 2020.

Congalton, R. G., Oderwald, R. G., \& Mead, R. A. (1983). Assessing landsat classification accuracy using discrete multivariate analysis statistical techniques. Photogrammetric Engineering and Remote Sensing, 49(12), 16711678.

Evans, E. (2014). Trees of strength. Retrieved from http://www.ncsu.edu/project/ treesofstrength/benefits.htm on August 30, 2019.

FAO - Food and Agriculture Organization of the United Nations. (2012). FRA 2015 terms and definitions Forest Resources Assessment Working Paper No. 180. Rome.

FAO - Food and Agriculture Organization. (1997). Africa over landcover classification. Rome. Retrieved from http://www.fao.org/ forestry/fra/2620/en/ on August 17, 2019.

FAO-Food and Agriculture Organization of United Nations. (2001). Global forest resources assessment 2000: Main report. FAO Forestry Paper No. 140. Rome. Retrieved from http:/ / www.fao.org/forestry/fra/2620/en/

Federal Department of Forestry - Nigeria. (2019). National Forest Reference Emission Level (FREL) for the Federal Republic of Nigeria. Retrieved from https://redd.unfccc.int/ files/2019_submission_frel_nigeria.pdf.

Kotoky, P., Dutta, M. K., \& Borah, G. C. (2012). Changes in land use and land cover along the Dhansiri river Channel, assam a remote sensing and GIS approach. Journal Geological Survey of India, 79, 61-68.

Lambin, E. F., \& Geist, H. (2006). Land - use and land - cover change: Local processes and global impacts. Berlin: Springer.

Lillesand, T. M., Kiefer, R. W., \& Chipman, J. W. (2008). Remote sensing and image interpretation (Sixth edit). New York: John Wiley \& Sons Inc.

Livesley, S. J., Escobedo, F. J., \& Morgenroth, J. (2016). The Biodiversity of urban and periurban forests and the diverse ecosystem services they provide as socio-ecological systems. Forest, 7(12), 291. doi://10.3390/ f7120291.

Lung, T., \& Schaab, G. A. (2010). A comparative assessment of land cover dynamics of three protected forest areas in tropical eastern Africa. Environmental Monitoring and Assessment Volume, 161, 531-548. doi://10.1007/ s10661-009-0766-3.

Ogbodo, J. A., Oke, D. O., \& Dagba, B. I. (2015). The potential of synthetic aperture radar (SAR) imagery in automated detection of forest degradation features using visual and semi-automated analyses. In Landuse, Landuse Change and Forestry (pp. 57-77). New York: Nova Science Publishers, Inc.

Ogbodo, J. A., Tembe, E. T., \& Peter, J. G. (2017). Assessing the issues and prospects of sustainable forestry in Nigeria.WFO F@ rmletter, 9-12. Retrieved from https://www. researchgate.net/publication/314239587_ Assessing_the_issues_and_prospects_of_ sustainable_forestry_in_Nigeria on August $17,2019$.

Ogbodo, J. A., Wasige, E. J., Shuaibu, S. M., Dube, T., \& Anarah, S. E. (2019). Remote sensing of droughts impacts on maize prices using SPOT-VGT Derived Vegetation Index. In P. Castro, A. M. Azul, W. Leal Filho, \& U. M. Azeiteiro (Eds.), Climate ChangeResilient Agriculture and Agroforestry. Springer International Publishing.

Ontl, T. A., Janowiak, M. K., Swanston, C. W., Daley, J., Handler, S., Cornett, M., ... Patch, N. (2020). Forest management for carbon sequestration and climate adaptation. Journal of Forestry, 118(1), 86-101. doi://10.1093/ jofore/fvz062.

Salbitano, F., Borelli, S., Conigliaro, M., \& Chen, Y. (2016). Guidelines on urban and peri-urban forestry. FAO Forestry Paper No. 178. Rome.

Singh, A. (1989). Digital change detection techniques using remotely sensed data. International Journal of Remote Sensing, 10(6), 989-1003.

Sonti, S. H. (2015). Application of geographic information system (GIS) in forest management. Journal of Geography and Natural Disasters, 5(3), 1-5. doi://10.4172/21670587.1000145 .

Sustainable Development Solutions Network (SDSN) - Australia/Pacific Australia/ Pacific. (n.d.). Getting started with the SDGs in Universities. Sustainable Development Solutions Network (SDSN) - Australia/ Pacific Australia/Pacific. 
Tilahun, A., \&Teferie, B. (2015). Accuracy assessment of land use land cover classification using google accuracy assessment of land use land cover classification using google earth. American Journal of Environmental Protection, 4(4), 193-198. doi://10.11648/j. ajep.20150404.14.

Torahi, A. A. (2013). Forest mapping and change analysis, using satellite imagery in Zagros mountain Iran. Lebanese Science Journal, 14(2), 63-74.

Ukrainski, P. (2016). Classification accuracy assessment. Confusion matrix method. Retrieved from http://www.50northspatial. $\mathrm{org} /$ classification-accuracy-assessmentconfusion-matrix-method/ on August 31, 2019.

Wimberly, M. C., \& Ohmann, J. L. (2004). A multiscale assessmentof human and environmental constraints on forest land cover change on the Oregon (USA) coast range. Landscape Ecology, 19, 631-646. doi://10.1023/ B:LAND.0000042904.42355.f3.

World Bank. (2009). Environmental crisis or sustainable development opportunity? Transforming the charcoal sector in Tanzania: A Policy Note. Retrieved from http://siteresoufces.worldbank. org/EXTAFRREGTOPENERGY / Resources/717305-1355261747480/World_ Bank_Transforming_the_Charcoal_Sector_ in_Tanzania.pdf on April 28, 2020.
Xiao, J., Shen, Y., Ge, J., Tateishi, R., Tang, C., Huang, Y., \& Zhiying, L. (2006). Evaluating urban expansion and land use change in Shijiazhuang, China, using GIS and remote sensing. Landscape and Urban Planning, 75(12), 69-80.

Xiaojun, Y. (2011). Urban remote sensing: Monitoring, synthesis and modelling in the urban environment (First Edit). John Wiley \& Sons.

Yuan, F., Sawaya, K. E., Loeffelholz, B. C., \& Bauer, M. E. (2005). Land cover classification and change analysis of the twin cities (Minnesota) metropolitan area by multitemporal landsat remote sensing. Remote Sensing of Environment, 98, 317-328.

Zubair, A. O. (2006). Change detection in land-use and landcover using Remote sensing data and GIS: $A$ case study of Ilorin and its environs in Kwara State. University of Ibadan. 